\title{
The effect of chemotherapy on quality of life in patients with lung carcinoma
}

\author{
Ceyda Anar (*), Osman Altıparmak (**), İpek Ünsal (*), Saliha Altıparmak $\left(^{* * *}\right)$, Dursun Tatar (*), \\ Hüseyin Halilçolar $\left(^{*}\right)$
}

\begin{abstract}
SUMMARY
The aim of the present study was to determine the effect of chemotherapy on the quality of life of patients with lung carcinoma. Fifty patients who were receiving chemotherapy between January 2006 and January 2007 were included in the study. The quality of life questionnaire (QLQ C-30), lung cancer specific module (LC-13) of the European Organization for Research and Treatment of Cancer (EORTC), and visual analog scale (VAS) were used in data collection. Chemotherapy resulted in worsening of social functioning, as well as dyspnea, constipation, and alopecia, whereas coughing improved. The economic status of the patients became worse compared to the first chemotherapy period $(p<0.05)$. Chemotherapy led to a decrease in physical and social functioning in the patients with non-small cell lung cancer, and an increase in fatigue, nausea, insomnia, and constipation. No statistical significance was observed between the presence of metastases and quality of life. Pain negatively affected all subscales of the quality of life. Although no relationship was observed between the quality of life and sociodemographic characteristics, such as age and educational status, gender affected the quality of life, and the role, emotional, and cognitive functioning of the quality of life were worse in females compared to males. Sociodemographic characteristics had no significant impact on the quality of life of the patients with lung cancer. Pain negatively affected all areas of quality of life; indeed, the quality of life of the patients decreased as pain increased.
\end{abstract}

Key words: Chemotherapy, lung carcinoma, quality of life

ÖZET

Akciğer kanserli hastalarda kemoterapinin yaşam kalitesi üzerine etkisi Bu çalışmada akciğer kanserli hastalarda kemoterapinin yaşam kalitesi üzerine etkilerinin belirlenmesi amaçlanmışıı. Araşıımaya Ocak 2006 ile 0cak 2007 yılları arasında kemoterapi tedavisi gören 50 hasta alındı. Veri toplama aracı olarak Avrupa Kanser Araştırma ve Tedavi Organizasyonu (EORTC) Yaşam Kalitesi Anketi (QLQ C-30) ve akciğer kanseri modülü (LC-13) ile görsel analog ölçeği (VAS) kullanıldı. Kemoterapi tedavisi ile birlikte sosyal fonksiyonda azalma ve dispne, konstipasyon, alopeside artma ve öksürükte azalma saptandı. Olguların ekonomik durumları da birinci kemoterapi dönemindekine göre daha kötü bulundu $(p<0.05)$. Kemoterapi tedavisi ile birlikte küçük hücre dışı akciğer kanserli hastalarda fiziksel fonksiyon ve sosyal fonksiyon alanları azalmış, yorgunluk, bulantı, uykusuzluk, konstipasyon da artmıştır. Metastaz varlığı ile yaşam kalitesi arasında istatistiksel olarak anlamlı bir farklıık yoktu. Ağrı yaşam kalitesinin bütün alanlarını negatif yönde etkilemektedir. Yaş, eğitim durumu gibi sosyodemografik özelliklerle yaşam kalitesi arasında ilişki olmamakla birlikte, cinsiyet yaşam kalitesini etkilemektedir ve erkeklerde yaşam kalitesi rol fonksiyon, emosyonel fonksiyon ve kognitif fonksiyon alanları kadınlara göre daha iyidir. Akciğer kanserli hastalarda yaşam kalitesinin değerlendirilmesinde sosyodemografik özelliklerin anlamlı bir etkisi yoktur. Ağrı yaşam kalitesinin bütün alanlarını negatif yönde etkilemektedir ve olgularda ağrı arttıkça yaşam kaliteleri düşmektedir.

Anahtar kelimeler: Kemoterapi, akciğer kanseri, yaşam kalitesi

* Deparment of Pulmonology, Dr. Suat Seren Chest Diseases and Surgery Training and Research Hospital, İzmir

** Deparment of Pulmonology, Public Hospital, Manisa

***Department of Public Health, University of Celal Bayar, Manisa

Reprint request: Dr. Ceyda Anar, Deparment of Pulmonology, Dr. Suat Seren Chest Diseases and Surgery Training and Research Hospital, İzmir

E-mail: drceydaanar@hotmail.com

Date submitted: September 13, 2011 • Date accepted: February 15, 2012 • Published online: April 30, 2012

\section{Introduction}

Cancer is a health problem that causes severe and intensive health problems due to the disease itself and the therapy regimens, thus substantially affecting the quality of life of the patients (1). The aim of treatment in patients with cancer not only involves the determination of the therapeutic response, disease-free survival time, and expected longevity, but also relieving disease-related symptoms, as well as improving the quality of life and extending survival. Long-lasting cancer therapy with several side effects negatively affects the family, work, and social lives of the subject; thus, the patient experiences loss of role, loss of status, hopelessness, desperation, social isolation, and exhaustion, and the quality of life changes negatively (2-5).

The WHO has defined the quality of life as "individuals' perception of their position in life in the context of culture and value systems in which they live" (6). Health-related quality of life is mainly a composite of overall life quality determined by the health of the individual and is affected by clinical interventions (7).

In the present study, we aimed to determine the effects of chemotherapy on the quality of life in patients with lung cancer.

\section{Material and Methods}

The present study was designed as a prospective, descriptive and clinical study. Fifty patients who were inpatients and ambulatory patients with lung cancer and receiving chemotherapy treatment at the Izmir Dr. Suat Seren Chest Diseases and Surgery Training and Research Hospital between January 2006 and January 2007 were included in the study. Patients who were illiterate, had physical disorders of such severity that impairs collaboration, had cognitive disability and were receiving psychiatric therapy 
because of mental disease at the time of the investigation were excluded from the study. The data were collected from the participants in two phases (after the first and third cycles of chemotherapy) with a face-to-face interview technique. Primarily, a sociodemographic questionnaire was administered to the patients and their partners. The questionnaire was prepared by the investigators and consisted of $29 \mathrm{qu}-$ estions in 3 sections. The first section focused on the sociodemographic characteristics, such as age, occupation, education, and social security of the patient and his/her partner. The second section questioned the status of smoking and alcohol use of the patient and his/her partner, and the third section questioned the characteristics related to the disease. Then, the European Organization for Research and Treatment of Cancer quality of life questionnaire (EORTC QLQ30) and EORTC lung cancer specific module (LC-13) were applied to the patients. The questionnaires were translated into Turkish language by Güzelant et al., and its validation and reliability were assessed for the Turkish population among patients with lung cancer (8). The Cronbach alpha coefficient of the scale was determined to be $\geq 0.70$. As a result of the studies, the scale was considered valid and reliable $(9,10)$.

The quality of life sub-scales of the questionnaire were as follows:

- Physical functioning, the ability to maintain daily activities, dynamism, and exhaustion, activeness, and able to work at a job

- Role functioning, the presence of an obstacle that constrains the subject to do his/her work/daily activities and hobbies

- Emotional functioning, positive/negative emotions

- Cognitive functioning, difficulty in concentrating and remembering, and

- Social functioning, the effect of physical status and medical therapy on interpersonal relationships and on social activities.

The Visual Analog Scale (VAS) was used in order to assess the pain of the patients.

The data were analyzed using SPSS 10.00 package program. Descriptive statistics were represented as mean and standard deviation. The paired samples t-test, Wilcoxon signed-rank test, Mann-Whitney U test, and Pearson correlation were also used in the analysis of data. A p value $<0.05$ was considered as the level of significance.

\section{Results}

Of the patients, $84 \%$ were males, $64 \%$ were primary school graduates, $34 \%$ were employees, and $92 \%$ were married. Ninety-six percent of the patients had social security, of whom $60 \%$ were insured by social insurance institution. Seventy two percent of the patients were from nuclear families. Of the patients, $84 \%$ reported that they quit smoking, whereas $12 \%$ expressed that they were still smoking. The mean number of cigarettes per day was $24.4 \pm 14.3$ (range: 0-60) and the mean duration of smoking was $31.4 \pm 12.9$ years (range: 0-55 years). Sixty eight percent of the patients had non-small cell lung cancer (NSCLC), whereas $32 \%$ had small cell lung cancer (SCLC). Of the patients with NSCLC, $24 \%$ had adenocarcinomas, $40 \%$ had undifferentiated carcinomas, and $4 \%$ had squamous cell carcinomas. Of the patients with SCLC, $8 \%$ had limited lung cancer, whereas $24 \%$ had diffuse lung cancer. Metastasis was present in $56 \%$ of the patients. There was no statistically significant relationship between age and quality of life in patients with carcinoma (Table I).

When the sub-scale scores of the quality of life and gender were compared, the role and emotional functioning after the first cycle of chemotherapy and the emotional and cognitive functioning after the third cycle of chemotherapy were better in males compared to females $(\mathrm{p}<0.05)$. No statistically significant difference was determined between the genders regarding general health status ( $p>0.05$, Table II).

When the educational status of the patients was compared with the quality of life after the first and third cycles of chemotherapy, no statistically significant difference was determined between the educational status and quality of life ( $\mathrm{p}>0.05)$.

The physical and role functioning after the first cycle of chemotherapy and the emotional functioning after the third cycle of chemotherapy were better in the patients living in a large family as compared to those living in a nuclear family $(\mathrm{p}<0.05)$. There was no statistically significant difference between patients living in a large family and patients living in a nuclear family with respect to cognitive and social functioning $(\mathrm{p}>0.05)$.

It was determined that social functioning of patients decreased after chemotherapy treatment. The effect of chemotherapy on clinical findings included worsening of dyspnea, constipation, alopecia, and improvement in coughing. The economic status 
Table I. The relationship between age and quality of life among patients

\begin{tabular}{|c|c|c|c|c|c|c|c|}
\hline Age & & Role functioning & $\begin{array}{c}\text { Physical } \\
\text { functioning }\end{array}$ & $\begin{array}{l}\text { Emotional } \\
\text { functioning }\end{array}$ & $\begin{array}{c}\text { Cognitive } \\
\text { functioning }\end{array}$ & Social functioning & $\begin{array}{c}\text { General health } \\
\text { status }\end{array}$ \\
\hline \multirow{2}{*}{$\begin{array}{l}\text { 1st } \\
\text { Chemotherapy } \\
\text { treatment }\end{array}$} & ${ }^{*} r$ & 0.228 & 0.211 & 0.136 & 0.184 & 0.296 & -0.225 \\
\hline & $p$ & 0.112 & 0.142 & 0.348 & 0.202 & 0.037 & 0.116 \\
\hline \multirow{2}{*}{$\begin{array}{l}\text { 3rd } \\
\text { Chemotherapy } \\
\text { treatment }\end{array}$} & ${ }^{*} r$ & 0.203 & 0.132 & -0.018 & 0.236 & -0.007 & -0.0180 \\
\hline & $p$ & 0.157 & 0.362 & 0.902 & 0.099 & 0.963 & 0.212 \\
\hline
\end{tabular}

\begin{tabular}{|c|c|c|c|c|c|c|}
\hline & \multicolumn{6}{|c|}{ 3rd Chemotherapy treatment } \\
\hline & Female & Male & ${ }^{*} p$ & Female & Male & *p \\
\hline General health & $100 \pm 25$ & $107 \pm 55$ & 0.649 & $108 \pm 36$ & $125 \pm 37$ & 0.328 \\
\hline Physical functioning & $60 \pm 21$ & $71 \pm 22$ & 0.176 & $58 \pm 15$ & $64 \pm 29$ & 0.354 \\
\hline Role functioning & $62 \pm 19$ & $78 \pm 27$ & 0.025 & $62 . \pm 19$ & $76 \pm 22$ & 0.074 \\
\hline Emotional functioning & $50 \pm 26$ & $81 \pm 15$ & 0.003 & $47 \pm 29$ & $75 \pm 23$ & 0.008 \\
\hline Cognitive functioning & $75 \pm 19$ & $87 \pm 15$ & 0.105 & $62 \pm 19$ & $88 \pm 16$ & 0.001 \\
\hline Social functioning & $54 \pm 36$ & $87 \pm 17$ & 0.003 & $62 \pm 40$ & $75 \pm 19$ & 0.726 \\
\hline
\end{tabular}

of the patients was worse in the third cycle of chemotherapy than in the first cycle of chemotherapy $(\mathrm{p}<0.05$, Figure 1).

When the patients with NSCLC and SCLC were compared according to the chemotherapy cycles, it was determined that general health status, physical functioning, cognitive functioning, and social functioning were better in patients with NSCLC after the first cycle of chemotherapy. After the third cycle of chemotherapy emotional functioning was better in patients with NSCLC, whereas physical functioning was better in patients with SCLC $(\mathrm{p}<0.05)$. When the effect of chemotherapy on clinical findings was examined among patients with NSCLC and SCLC, it was determined that patients with SCLC experienced hemoptysis, dysphagia, neuropathy, and pain more severely during the first cycle of chemotherapy and experienced alopecia more severely during the third cycle of chemotherapy as compared to those with NSCLC $(\mathrm{p}<0.05)$.

When the patients with NSCLC and with SCLC were compared with respect to the effect of the responses to the first and third cycles of chemotherapy on the quality of life, a decrease in physical and social functioning areas was demonstrated in the patients with NSCLC along with chemotherapy treatment. When it was evaluated regarding clinical findings, complaints about fatigue, nausea, insomnia, and constipation were increased and also economic status was worsened in patients with NSCLC compared with the pre-treatment period. An improvement was determined in general health status and in physical functioning, as well as in loss of appetite among patients with SCLC. No statistically significant difference was determined between the first and third cycles of chemotherapy regarding other areas (Table III).

When the patients with NSCLC and SCLC were compared regarding the effect of responses to the first and third cycles of chemotherapy on LC-13 cli-

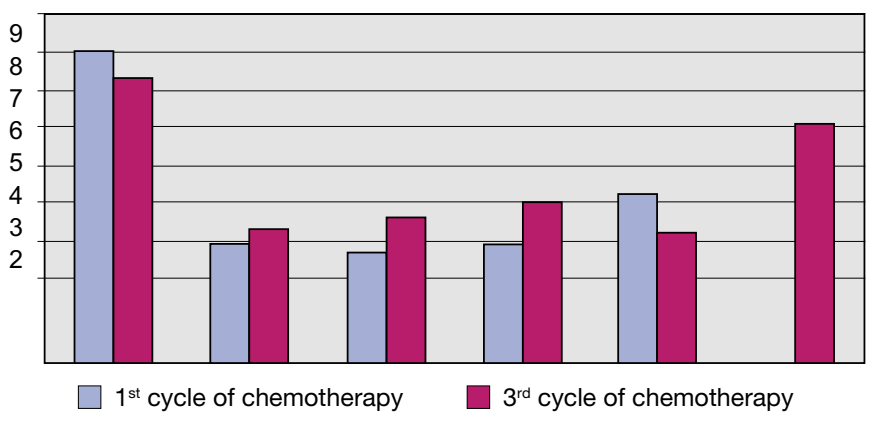

Figure 1. Comparison of quality of life of the patients in the first and third cycles of chemotherapy (The quality of life questionnaire-30 and lung cancer specific module-13, $p<0.05$ ) 
nical findings, it was determined that dyspnea, oral ulcerations, alopecia, pain in the arms and shoulders, as well as other pains, had worsened in the patients with NSCLC, whereas only alopecia had worsened in the patients with SCLC (Table IV).

When the presence of metastasis and quality of life after the first and third cycles of chemotherapy were compared among patients, no statistically significant difference was determined between the presence of metastases and quality of life among patients with lung carcinoma $(\mathrm{p}<0.05)$.

There was a negative correlation between VAS and quality of life among patients. The quality of life worsened when the pain increased. There was no statistically significant difference between the VAS scores of patients after the first and third cycles of chemotherapy ( $\mathrm{p}>0.05)$.

\section{Discussion}

Cancer is a group of diseases that negatively affects both the patient and their relatives because of the word "cancer" creating fear, as well as the anxiety about the future and the stress that would probably be experienced in the course of the disease and the treatment. A progressive worsening is observed in the quality of life of patients with carcinoma along with the progression of the disease. The quality of life of the patients with advanced carcinoma is also worsened due to the cancer-related symptoms or signs, such as pain, dyspnea, fatigue, and weight loss $(5,9,11)$.

In the studies investigating the relationship between sociodemographic characteristics and quality of life, it has been determined that age has no effect on the symptoms, function, and mental health of the patients, whereas a weak or no relationship has been

Table III. Comparison of the patients with non-small cell lung cancer and with small cell lung cancer regarding the effect of responses to the first and third cycles of chemotherapy on the quality of life questionnaire-30

\begin{tabular}{|c|c|c|c|c|c|c|}
\hline \multirow[b]{2}{*}{ QLQ-30 } & \multicolumn{3}{|c|}{ Patients with small cell lung cancer } & \multicolumn{3}{|c|}{ Patients with non-small cell lung cancer } \\
\hline & $\begin{array}{c}1 s t \\
\text { Chemotherapy } \\
\text { treatment }\end{array}$ & $\begin{array}{c}\text { 3rd } \\
\text { Chemotherapy } \\
\text { treatment }\end{array}$ & ${ }^{*} p$ & $\begin{array}{c}1 s t \\
\text { Chemotherapy } \\
\text { treatment }\end{array}$ & $\begin{array}{c}\text { 3rd } \\
\text { Chemotherapy } \\
\text { treatment }\end{array}$ & ${ }^{*} p$ \\
\hline General health & $120 \pm 47$ & $121 \pm 40$ & 0.921 & $75 \pm 48$ & $125 \pm 31$ & 0.921 \\
\hline Physical functioning & $76 \pm 19$ & $57 \pm 28$ & $<0.001$ & $55 \pm 20$ & $76 \pm 18$ & $<0.001$ \\
\hline Social functioning & $85 \pm 25$ & $74 \pm 26$ & 0.021 & $75 \pm 21$ & $70.8 \pm 18$ & 0.021 \\
\hline Fatigue & $28 \pm 18$ & $39 \pm 28$ & 0.044 & $44 \pm 32$ & $40 \pm 17$ & 0.044 \\
\hline Nausea & $18 \pm 30$ & $33 \pm 30$ & 0.034 & $33 \pm 37$ & $12 \pm 14$ & 0.034 \\
\hline Insomnia & $15 \pm 20$ & $37 \pm 36$ & 0.002 & $29 \pm 26$ & $25 \pm 22$ & 0.002 \\
\hline Loss of appetite & $23 \pm 30$ & $29 \pm 32$ & 0.422 & $45 \pm 41$ & $20 \pm 29$ & 0.422 \\
\hline Constipation & $17 \pm 26$ & $37 \pm 30$ & 0.001 & $45 \pm 41$ & $33 \pm 34$ & 0.001 \\
\hline Economic status & $21 \pm 30$ & $39 \pm 46$ & 0.004 & $45 \pm 48$ & $41 \pm 44$ & 0.004 \\
\hline
\end{tabular}

Table IV. Comparison of the patients with non-small cell lung cancer and small cell lung cancer regarding the effect of responses to the first and third cycles of chemotherapy on lung cancer specific module-13 clinical findings

\begin{tabular}{lcccccc}
\hline $\begin{array}{l}\text { Lung cancer specific } \\
\text { module-13 }\end{array}$ & \multicolumn{2}{c}{ Patients with small cell lung cancer } & $\begin{array}{c}\text { Pst } \\
\text { Chemotherapy } \\
\text { treatment }\end{array}$ & $\begin{array}{c}\text { 3rd } \\
\text { Chemotherapy } \\
\text { treatment }\end{array}$ & $\boldsymbol{p}$ & \multicolumn{2}{c}{$\begin{array}{c}\text { Patients with non-small cell Iung cancer } \\
\text { Chemotherapy } \\
\text { treatment }\end{array}$} & $\begin{array}{c}\text { 3rd } \\
\text { Chemotherapy } \\
\text { treatment }\end{array}$ \\
\hline Dyspnea & $26.1 \pm 17.2$ & $38.5 \pm 22.5$ & $\mathbf{0 . 0 4 6}$ & $31.9 \pm 23.9$ & $26.3 \pm 18.9$ \\
Oral ulcerations & $5.8 \pm 12.8$ & $19.6 \pm 34.9$ & $\mathbf{0 . 0 2 7}$ & $12.5 \pm 23.9$ & $12.5 \pm 16.6$ & 0.414 \\
Alopecia & $17.6 \pm 33.0$ & $50.9 \pm 35.0$ & $\mathbf{0 . 0 0 1}$ & $20.8 \pm 29.5$ & $83.3 \pm 24.3$ & 0.957 \\
Arm and shoulder pain & $17.6 \pm 23.5$ & $27.4 \pm 28.9$ & $\mathbf{0 . 0 1 9}$ & $41.6 \pm 28.5$ & $37.5 \pm 36.2$ & 0.001 \\
Other pains & $15.6 \pm 23.5$ & $27.4 \pm 26.5$ & $\mathbf{0 . 0 1 5}$ & $29.1 \pm 36.2$ & $16.6 \pm 24.3$ \\
\hline
\end{tabular}

${ }^{*}$ : Paired samples t-test, ${ }^{* *}$ : Wilcoxon signed-rank test 
determined between age and quality of life $(10,12)$. In the present study, as well, no relationship was found between quality of life and age, and educational status. The lack of correlation between age and quality of life among patients with carcinoma has suggested that the patients may experience the same disease- or treatment-related problems regardless of their ages.

In the studies investigating the role of gender, it has been indicated that women experience cancerrelated psychological trauma more severe than men and female gender is an efficacious factor in the development of anxiety and depression (12-14). In consistent with the literature, in the present study the role, emotional, and cognitive functioning dimensions of quality of life were significantly worse in female patients compared to male patients $(\mathrm{p}<0.05)$. This may be attributed to the fact that females are more emotional and experience the problems more intensely than males.

Although the primary goal of the clinicians is to prolong survival in cancer patients, providing a better quality of life, or at least preserving the current condition is paramount in diseases with poor prognosis, such as lung cancer, in which therapy cannot provide a significant prolongation in survival (15). In recent years, studies investigating the effect of cancer therapy on quality of life have been gradually increasing. In the study performed by Montazeri et al. on 129 patients with lung cancer, they evaluated the quality of life before and after the therapy, and determined a decrease in the functional areas of QLQ-30 quality of life and general health status, as well as an increase in alopecia, constipation, and oral ulceration rates (16). Similarly, there are studies in the literature showing that chemotherapy worsens quality of life in patients with lung carcinoma (17-21). In the present study, chemotherapy administration led to a decrease in social functioning of the patients. When the effect of chemotherapy on clinical findings was examined, a worsening was observed in dyspnea, constipation, and alopecia, whereas an improvement was observed in coughing. The economic status of the patients was also worse after third cycle of chemotherapy as compared to the first cycle of chemotherapy $(\mathrm{p}<0.05)$.

SCLC is a type of carcinoma susceptible to chemotherapy, and systemic chemotherapy is the primary form of treatment. This was first shown in 1948 by a tumor regression of $>50 \%$ after treatment with methyl-bis-chloroethyl amine $\mathrm{HCl}$. In a randomized study conducted in 1969, supportive treatment was compared with cyclophosphamide in cases with advanced stage SCLC. The mean survival was $>2$-fold in the chemotherapy arm and the efficacy of chemotherapy was definitely shown. In subsequent studies, it was shown that a number of antineoplastic agents were effective in SCLC (22). Gridelli et al. also reported that patients with SCLC responded better to chemotherapy, whereas the treatment response of NSCLC patients might be better when chemotherapy was applied together with surgery, and the quality of life of the patients would be influenced by appropriate treatment (20). Bircan et al. reported an improvement in general health status, and in emotional and role functioning dimensions of quality of life in patients with SCLC along with chemotherapy treatment, whereas they reported an improvement only in general health status in patients with NSCLC (23). In the present study, an improvement was determined in general health status and physical functioning of the patients with SCLC along with chemotherapy. When the patients were evaluated in terms of clinical findings, an improvement was assessed in loss of appetite. However, in patients with NSCLC, a worsening was observed in physical and social functioning, as well as in fatigue, nausea, insomnia, and constipation, and in economic status.

In the present study, in consistent with the literature, no statistically significant difference was determined between the patients with metastatic and non-metastatic lung cancer in terms of quality of life $(8,17)$. This result showed that the patients experienced both the effects of the disease (cancer) and the therapy regardless of the extent of the disease, and quality of life was affected.

Cancer-related pain is a complex and comprehensive notion having emotional, affective, cognitive, and behavioral aspects. It is encountered in one-half of overall cancer patients and in $>90 \%$ of the patients with advanced-stage carcinoma. Pain, which is an important problem for cancer patients, leads to anxiety and emotional distress in the patient, and negatively affects the functional capacity; moreover, inhibits the ability of accomplishing familial, social, and occupational roles (24-26). According to data, pain negatively affects all dimensions of quality of life, and successful control of pain would improve quality of healthy life (QOHL). 
In conclusion, it was determined that sociodemographic characteristics, such as age and educational status, had no significant effect on the evaluation of quality of life among patients with lung cancer; however, male patients had better quality of life. A worsening was observed in social functioning, as well as in the economic status of the patients after the third cycle of chemotherapy compared to the first cycle of chemotherapy. In the sub-group evaluation of the patients, it was determined that the quality of life of the patients with SCLC was affected more positively as compared to that of patients with NSCLC. Pain negatively affected all dimensions of quality of life and as the pain increased quality of life was getting worse.

\section{References}

1. Wynder EL, Hoffman D. Smoking and lung cancer: scientific challenges and opportunities. Cancer Res 1994; 54: 5284-5285.

2. Göksel T, Güzelant A. Akciğer kanserinde yaşam kalitesi değerlendirmeleri. In: Hastürk S, Yüksel M (eds). Akciğer Kanseri. İstanbul: Bilmedya Grup, 2000: 359-375.

3. Given CW, Given BA, Stommel M. The impact of age, treatment, and symptoms on the physical and mental health of cancer patients. A longitudinal perspective. Cancer 1994; 74 (Suppl): 2128-2138.

4. Hajiro T, Nishimura K, Tsukino M, Ikeda A, Koyama $\mathrm{H}$, Izumi T. Comparison of discriminative properties among disease spesific questionnaires for measuring health-related quality of life in patients with chronic obstructive pulmonary disease. Am J Respir Crit Care Med 1998; 157: 785-790.

5. Gültekin Z, Pınar G, Pınar T ve ark. Akciğer kanserli hastaların yaşam kaliteleri ve sağlık bakım hizmet beklentileri. Uluslararası Hematoloji Onkoloji Dergisi 2008; 15: 99-106.

6. Saxena S, Orley J; on behalf of the WHOQOL Group. Quality of life assessment: The world health organization perspective. Eur Psychiatry 1997; 12 (Suppl 3): 263S-266S.

7. Ware JE Jr. The status of health assessment 1994. Annu Rev Public Health 1995; 16: 327-354.

8. Guzelant A, Goksel T, Ozkok S, Tasbakan S, Aysan T, Bottomley A. The European Organization for Research and Treatment of Cancer QLQ-C30: an examination into the cultural validity and reliability of the Turkish version of the EORTC QLQ-C30. Eur J Cancer Care (Engl) 2004; 13: 135-144.

9. Griffin JP, Nelson JE, Koch KA, et al. American College of Chest Physicians. End-of-life care in patients with lung cancer. Chest 2003; 123 (Suppl 1): 312S-331S.
10. Ganz PA, Schag CA, Cheng HL. Assessing the quality of life a study in newly-diagnosed breast cancer patients. J Clin Epidemiol 1990; 43: 75-86.

11. Kvale PA, Simoff M, Prakash UB. American College of Chest Physicians. Lung cancer. Palliative care. Chest 2003; 123 (Suppl 1): 284S-311S.

12. Rustoen T, Moum T, Wiklund I, Hanested BR. Quality of life in newly diagnosed cancer patients. J Adv Nurs 1999; 29: 490-498.

13. Arslan S, Bölükbaş N. Kanserli hastalarda yaşam kalitesinin değerlendirilmesi Atatürk Üniversitesi HYO Dergisi 2003; 6: 38-47.

14. Pandey M, Sarita GP, Devi N, Thomas BC, Hussain BM, Krishan N. Distress, anxiety, and depression in cancer patients undergoing chemotherapy. World J Surg Oncol 2006; 4: 68 .

15. Gralla RJ. Quality-of-life considerations in patients with advanced lung cancer: effect of topotecan on symptom palliation and quality of life. Oncologist 2004; 9 (Suppl 6): $14-24$.

16. Montazeri A, Hole DJ, Milroy R, McEwen J, Gillis CR. Quality of life in lung cancer patients: does socioeconomic status matter? Health Qual Life Outcomes 2003; 1: 19 (http://www.hqlo.com/content/1/1/19).

17. Price DD, McGrath PA, Rafii A, Bukingham B. The validation of visual analogue scales as ratio scale measures for chronic and experimental pain. Pain 1983; 17: 45-56.

18. Chie WC, Yang CH, Hsu C, Yang PC. Quality of life of lung cancer patients: validation of the Taiwan Chinese version of the EORTC QLQ-C30 and QLQ-LC13. Qual Life Res 2004; 13: 257-262.

19. Cella D. The Functional Assessment of Cancer TherapyLung and Lung Cancer Subscale assess quality of life and meaningful symptom improvement in lung cancer. Semin Oncol 2004; 31 (Suppl 9): 11-15.

20. Gridelli C, Perrone F, Nelli F, Ramponi S, De Marinis F. Quality of life in lung cancer patients. Ann Oncol 2001; 12 (Suppl 3): S21-S25.

21. Montazeri A, Milroy R, Hole D, McEwen J, Gillis CR. Quality of life in lung cancer patients: as an important prognostic factor. Lung Cancer 2001; 31: 233-240.

22. Engin K, Özyardımcı N. Akciğer Kanserleri-Tanı ve Tedavide Temel İlkeler ve Uygulamalar. 1. baskı. İstanbul: Avrupa Tıp Kitapçllık, 2001: 135-183.

23. Bircan A, Berktaş B, Bayız H, Başay N, Bircan S, Berkoğlu M. Effects of chemotherapy on quality of life for patients with lung cancer. Turk Resp J 2003; 4: 61-65.

24. Wargo BW, Burton AW. Cancer pain. In: Wallace MS, Staats PS (eds). Pain Medicine and Management: Just the Facts. International Edition. New York: McGraw Hill Company, 2005: 183-189.

25. Katz N. The impact of pain management on quality of life. J Pain Symptom Manage 2002; 24 (Suppl 1): S38-S47.

26. Yıldırım Y, Uyar M, Fadıllıŏ̆lu Ç. Kanser ağrısı ve yaşam kalitesine etkisi. Ağrı Dergisi 2005; 17: 17-22. 